\title{
Construção da reflexão na escrita acadêmica por professores em formação inicial
}

\section{Construction of reflection in academic writing by pre-service teachers}

\author{
Wagner Rodrigues Silva* \\ Universidade Federal do Tocantins \\ Palmas - Tocantins / Brasil \\ Kellen Lucy Santos Silva** \\ Universidade Federal do Tocantins \\ Araguaína - Tocantins / Brasil \\ Lucieny de Castro Borba*** \\ Universidade Federal do Tocantins \\ Araguaína - Tocantins / Brasil
}

\begin{abstract}
RESUMO: Investigamos os usos de complexos oracionais em que as orações primárias são identificadas como orações mentais na escrita acadêmica reflexiva realizada em relatórios escritos por professores em formação inicial. Os textos foram produzidos como avaliação final de disciplinas obrigatórias de estágio supervisionado em três licenciaturas, Língua Portuguesa, Língua Inglesa e Matemática, sendo dada ênfase a essa última. As principais categorias analíticas são os componentes experiencial e lógico, integrantes da metafunção ideacional da linguagem, proposta na abordagem gramatical da Linguística SistêmicoFuncional. Os resultados mostraram a construção recorrente de representações dos próprios autores como experienciadores dos fenômenos atrelados aos processos mentais perceptivos e cognitivos. Esses processos são responsáveis, respectivamente, pela elaboração de sequências textuais descritivas e narrativas e pela explicitação de posicionamentos mais críticos.
\end{abstract}

PALAVRAS-CHAVE: Letramento do professor; Licenciatura em matemática; Linguística Sistêmico-Funcional.

\footnotetext{
*wagnersilva@uft.edu.br

**kellenlucyuft@live.com

*** lucienyborba@hotmail.com
} 


\begin{abstract}
We have investigated the uses of clause complexes in which primary clauses are identified as mental clauses in reflective academic writing present in reports written by pre-service teachers. The texts were produced as a final evaluation for compulsory Teaching Practice disciplines in Portuguese, English, and Mathematics Teacher Education courses, with greater emphasis on the latter. The main analytical categories are the experiential and logic components that integrate the ideational metafunction of language proposed in the grammatical approach of Systemic Functional Linguistics. Results have shown the recurrent construction of representations by the authors themselves as those that experience the phenomena related to perceptive and cognitive mental processes. These processes are responsible, respectively, for the elaboration of descriptive and narrative textual sequences, as well as for the explicitness of more critical positioning.
\end{abstract}

KEYWORDS: Teacher literacy; Mathematics Teacher Education course; Systemic Functional Linguistics.

\title{
1 Introdução
}

Na presente pesquisa, analisamos a escrita reflexiva acadêmica realizada no gênero relatório de estágio supervisionado, produzido por professores em formação inicial, aqui denominados de alunos-mestre, especialmente numa Licenciatura em Matemática. A análise gramatical realizada a partir de complexos oracionais mentais, característicos da referida escrita acadêmica, justifica-se pelo nosso interesse em compreender a gênese da atividade linguística de reflexão sobre a prática pedagógica, necessária para a formação do professor autônomo. ${ }^{1}$

Considerando como principais dados desta pesquisa 07 (sete) relatórios de estágio supervisionado, apresentados como produto escrito da última atividade avaliativa da disciplina, investigamos as ocorrências de orações paratáticas extensivas utilizadas como complementos de oraçoés mentais perceptivas hipotáticas, além de orações hipotáticas projetadas por orações mentais cognitivas. A investigação dos complexos oracionais mentais por percepção e

\footnotetext{
${ }^{1}$ Esta pesquisa foi apresentada no I International Congress of Critical Applied Linguistics: Language, Action and Transformation (ICCAL), na Universidade de Brasília (UNB), em Outubro de 2015. Foi desenvolvida no âmbito do seguinte projeto: "Estudo gramatical-discursivo da escrita reflexiva profissional produzida por professores em formação inicial" (CNPq 446235/2014-8). Contribui para as atividades dos seguintes grupos de pesquisa: Práticas de Linguagens - PLES (UFT/ CNPq); Sistêmica Através das Línguas - SAL (PUCSP/CNPq).
} 
por cognição² se justifica pelo objetivo de compreender escolhas linguísticas realizadas pelos alunos-mestre quando inseridos em situações de reflexão pela escrita a respeito de experiências vivenciadas por eles na escola básica, no período de estágio obrigatório da licenciatura.

A Linguística Sistêmico-Funcional (LSF) é assumida como principal referencial teórico para análise linguística dos dados. Dentre as três metafunções da linguagem, ideacional, interpessoale textual, propostas na LSF, focalizamos mais diretamente os componentes experiencial e lógico constitutivos da primeira metafunção citada, responsáveis, respectivamente, por discursos produzidos a partir da escolha de participantes, processos e circunstâncias nas orações e da articulação entre orações gramaticais no registro escrito investigado (cf. EGGINS, 2004; HALLIDAY; MATTHIESSEN, 2014; THOMPSON, 2014). Ao estabelecermos elos entre as orações, construímos representações de coisas no nosso mundo exterior e, em especial, considerando nosso interesse investigativo pelas orações mentais, no nosso mundo interior, compreendendo aí as atividades reflexivas retrospectivas e prospectivas, necessárias para a transformação das práticas pedagógicas na escola básica (cf. SILVA, 2014a).

Os principais relatórios investigados foram produzidos por alunosmestre concluintes do primeiro estágio obrigatório da Licenciatura em Matemática. A disciplina objetiva possibilitar ao aluno "analisar e refletir o processo de ensino da matemática no ensino fundamental e médio, visando possibilitar novas práticas educativas" (ARAGUAÍNA, 2012, p. 70). Os alunos-mestre ainda não ministram aulas na escola básica, apenas observam e analisam a dinâmica do trabalho pedagógico na instituição, em especial as aulas da disciplina de Matemática. Nesse contexto, o relatório de estágio se configura como um espaço linguístico-discursivo para compartilhar a experiência de observação vivenciada do estágio obrigatório em instituições de ensino básico. Quando bem aproveitada, a escrita do relatório pode contribuir para a formação de um profissional crítico da própria prática profissional, além de oportunizar um trabalho mais produtivo sobre a escrita acadêmica com as particularidades do registro reflexivo profissional (cf. SILVA, 2014a; 2013).

Além da Introdução, das Considerações Finais e das Referências, este artigo está organizado em duas principais seções. Em Abordagem sistêmico-funcional

\footnotetext{
${ }^{2}$ Quando utilizamos a denominação complexo oracional mental, referimo-nos aos complexos em que a oração primária é realizada por processos mentais.
} 
da escrita como atividade sociossemiótica, descrevemos o percurso investigativo desenvolvido e caracterizamos a escrita acadêmica reflexiva investigada. A caracterização dessa escrita é realizada à luz da síntese teórica a respeito do componente experiencial da gramática da oração e do componente lógico do complexo oracional, na perspectiva da abordagem sistêmico-funcional. Em Reflexões construidas na escrita acadêmica, apresentamos uma análise qualitativa e quantitativa da composição gramatical dos complexos oracionais mentais identificados. Essa análise é realizada pela mediação de categorias linguísticas focalizadas na síntese teórica previamente apresentada.

\section{Abordagem sistêmico-funcional da escrita como atividade sociossemiótica}

A escrita acadêmica reflexiva é realizada pela atividade linguística de representação da experiência do estágio supervisionado, vivenciada por alunos-mestre num espaço social construído entre a escola básica e a universidade, instaurando o que é denominado de intercontextualidade, conforme proposta de Meurer (2004, p. 135) para identificar "a condição em que dois ou mais contextos se interligam e interpenetram em uma determinada prática social". ${ }^{3}$

Essas instituições de ensino nem sempre interagem de forma harmoniosa, mesmo em situações promissoras como os estágios supervisionados, quando poderiam ser desenvolvidas práticas pedagógicas colaborativas e fortalecedoras dos atores sociais participantes. Nas palavras de Gisi, Martins e Romanowski (2009, p. 208), o estágio nos cursos de licenciatura é compreendido como

uma oportunidade de inserção numa realidade, no caso escolas de educação básica, permitindo a confrontação do saber acadêmico com o saber da escola, permitindo aos estudantes apreender como se dão as relações de trabalho. O exercício de inserção e distanciamento, quando permeado de análises do processo vivenciado, prepara o futuro professor para a possibilidade de contribuir com a transformação. No

\footnotetext{
${ }^{3}$ Ainda nos termos do autor, "na intercontextualidade um texto é 'levado' para outro contexto e dá-se o compartilhamento de características de ambos, muitas vezes com predomínio de um sobre o outro. (...) Com a complexidade do mundo contemporâneo, muitos contextos se sobrepõem e se mesclam, com crescente grau de intercontextualidade" (MEURER, 2004, p. 135).
} 
entanto, verifica-se que, muitas vezes, o estágio se constitui em uma mera obrigação burocrática, desconsiderando seu potencial na formação dos alunos e mesmo quando se valoriza o estágio na formação profissional são muitas as dificuldades enfrentadas pelos professores supervisores.

Ao se configurar textualmente por meio do gênero relatório de estágio, a escrita que se deseja reflexiva se constitui como um espaço de atividade intelectual, possibilitando ao aluno-mestre registrar negociações constitutivas do processo de formação profissional. Envolve a apropriação ou construção de saberes teóricos e da prática, num espaço social sobre o qual é lançado um olhar diferenciado, não mais semelhante ao do aluno egresso da escola básica. A escrita reflexiva estende as experiências vivenciadas, aproxima o espaço escolar e o universitário, podendo instaurar um terceiro espaço social conectado por diversos fios que se alastram pela vida do aluno-mestre. Nessa escrita, são encontradas ainda marcas das relações interpessoais tecidas nas interações instauradas, justificando a caracterização desse registro acadêmico diferenciado como uma atividade sociossemiótica.

Realizamos uma análise linguística dos documentos selecionados com propósito de explicitar discursos depreendidos a partir do exame da materialidade textual, conforme pressupostos analíticos da LSF, cuja teoria está ancorada no exame de escolhas léxico-gramaticais para a construção do texto configurado em algum gênero, aqui compreendido numa perspectiva textual informada por pressupostos sistêmico-funcionais, como prática social culturalmente moldada e realizada na materialidade textual. Essas escolhas realizadas pelo enunciador, os alunos-mestre nos relatórios de estágio investigados, são motivadas especialmente por práticas sociais características dos diferentes contextos que informam as situações enunciativas. Nas palavras de Meurer (2004, p. 134), na sistêmicofuncional "não se analisa um texto unicamente em termos dos elementos lexicogramaticais. Ao invés disso, cada significado deve ser relacionado simultaneamente a rotinas sociais e a formas linguísticas" (sic).

A propriedade funcional da teoria gramatical que utilizamos se justifica pelos significados ou discursos produzidos pelas escolhas linguísticas realizadas na produção da linguagem, concebida inicialmente "como um sistema de escolhas, utilizada em um meio social de modo que os indivíduos possam desempenhar papéis sociais" (FUZER; TICKS; CABRAL, 2012). A propriedade sistêmica, por sua vez, justifica-se pelo fato de as escolhas linguísticas serem realizadas em sistemas ou redes semânticas, responsáveis 
por opções de escolhas léxico-gramaticais desencadeadoras de significados ou discursos potenciais (HALLIDAY; MATTHIESSEN, 2014; MEURER, 2004; THOMPSON, 2014).

Considerando tais propriedades, o texto e o contexto são interdependentes na análise linguística produzida à luz da LSF. De acordo com Halliday e Matthiessen (2014, p. 3), "numa primeira instância, a língua corresponde a um recurso para produzir significado, ao passo que o texto é um processo responsável por produzir significado em contexto". "Não raro", a interdependência entre texto e contexto "se torna naturalizada e despercebida" (MEURER, 2004, p. 135). Em contextos pontuais, a naturalização das escolhas linguísticas resulta na reprodução de discursos ou de representações particulares do mundo em nosso entorno. Nos relatórios investigados, por exemplo, essas escolhas resultam em representações construídas a respeito de diferentes espaços e atores sociais envolvidos na escola de educação básica (como alunos, professores, materiais didáticos, dentre outros), local de realização dos estágios obrigatórios das licenciaturas.

Conforme representado na Figura 01, o funcionamento da linguagem se organiza em estratos, identificados por categorias orientadoras da análise linguística. O contexto sociocultural é apreendido pelas seguintes subcategorias: contexto de situação e contexto de cultura (EGGINS, 2004; EGGINS; MARTIN, 1997). Conforme investigações realizadas no grupo de pesquisa PLES (SILVA, 2015; 2014a; 2014b; SILVA; ESPINDOLA, 2016), o primeiro compreende desde circunstâncias mais imediatas que interferem na produção da linguagem, como conteúdo discutido (campo), forma de organização e circulação textual (modo), além das relações interpessoais entre pessoas envolvidas na escrita (relaçôes), a exemplo dos formadores e alunos-mestre, ignorando como interlocutores, muitas vezes, os professores colaboradores dos estágios na escola de educação básica. O contexto de cultura compreende outras circunstâncias não imediatas, como a escolha do trabalho escrito final da disciplina, apresentado em forma de relatório ou, até mesmo, identificado como memorial. São determinadas por aspectos históricos, construídos na interação em instituições de formação docente (cf. SILVA, 2014a; SILVA; ESPINDOLA, 2013).

No caso específico dos relatórios da Licenciatura em Matemática, o formador, colaborador desta pesquisa, utilizou-se de encaminhamentos diferenciados para orientar a elaboração do que denominou de memorial, contrapondo-se à produção da escrita burocratizada do relatório de 
estágio, que, muitas vezes, é caracterizado pelo distanciamento dos alunosmestre em relação aos fatos relatados, resultado da reprodução de uma tradição acadêmica característica das licenciaturas brasileiras. Nas próprias palavras do formador, o uso do gênero memorial, motivado por recentes estudos acadêmicos sobre formação do professor de matemática, permite que os alunos-mestre "tenham um espaço para refletir sobre suas ações docentes realizadas, mediante resgate mnemônico, além dos registros escritos que fazem de suas aulas". ${ }^{4}$ Considerando nossa compreensão dos gêneros textuais como prática social culturalmente moldada e realizada na materialidade textual, reiteramos que o formador tentou alterar a estratégia pedagógica, ao eleger uma forma linguística diferenciada de apresentação das experiências vivenciadas no estágio obrigatório, com as impressões mais explícitas dos alunos-mestre sobre a prática pedagógica, deixando o propósito interativo do gênero selecionado mais definido em função da formação inicial do professor.

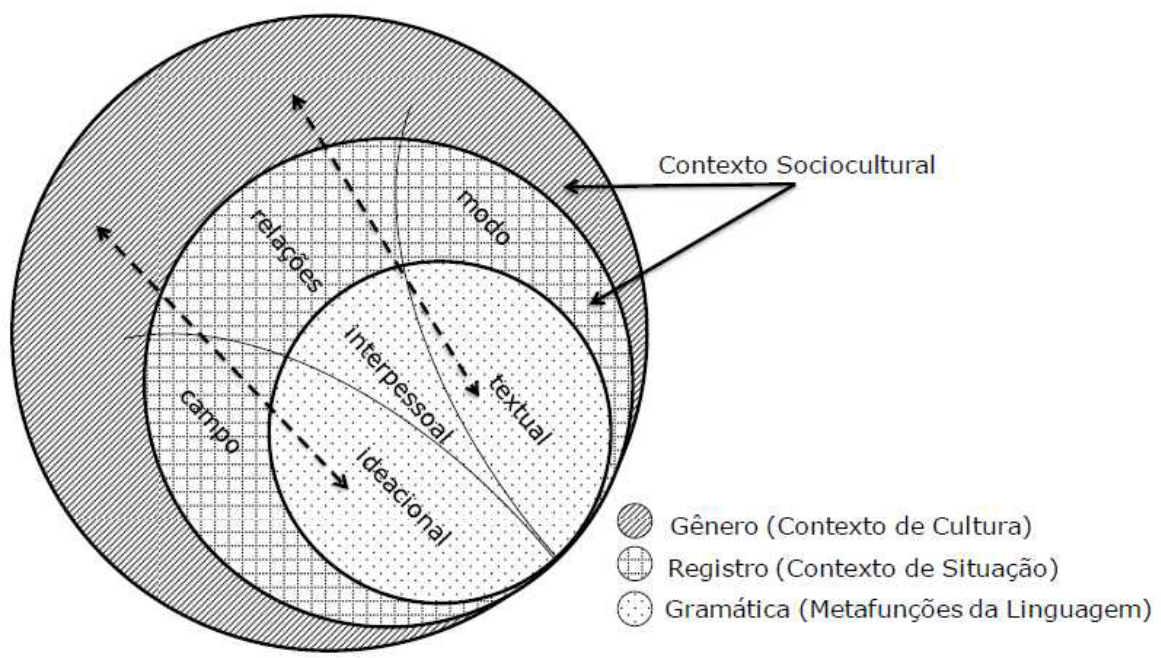

FIGURA 01: Relação entre língua e contexto em estratos ${ }^{5}$

\footnotetext{
${ }^{4}$ Essa citação foi reproduzida a partir da resposta dada pelo formador a algumas perguntas que realizamos a respeito do contexto de produção escrita dos documentos aqui investigados. Essa interação com o formador foi produzida por e-mail cujas respostas serão transcritas oportunamente em outros momentos deste artigo.

${ }^{5}$ Figura adaptada de Martin (2012[1997], p. 189).
} 
Ao investigarmos a escrita acadêmica utilizada na formação inicial do professor, podemos caracterizar a universidade como contexto cultural de referência, considerando "a relevância e a abrangência das práticas sociais produzidas nessa instituição para as atividades da disciplina acadêmica" (SILVA, 2015, p. 45). Conforme destacado por Meurer (2004) e Silva (2014b), o contexto de cultura demanda maior aprofundamento teórico por pesquisadores para ser utilizado de forma mais eficaz em pesquisas linguísticas. Como resposta preliminar à inquietação explicitada, o primeiro autor se propôs a "desenvolver uma fundamentação sociológica abrangente para a descrição e explicação da interdependência entre textos e contextos mais amplos" (MEURER, 2004, p. 135); o segundo autor propôs a realização de três atividades investigativas em torno da instituição focalizada na pesquisa, resultando na caracterização do contexto de cultura: revisão da literatura científica existente sobre o assunto, preferencialmente numa perspectiva não disciplinar; etnografia do espaço social a partir de fontes diversas de pesquisa; e descrição do gênero configurador dos dados (SILVA, 2014b).

O funcionamento do contexto sociocultural é explorado pelas noções de gênero e de registro. "O conceito de gênero é usado para descrever o impacto do contexto de cultura na língua" (EGGINS, 2004, p. 9). ${ }^{6}$ O contexto de cultura é responsável por informar o texto num grau mais extenso, o gênero se localiza no estrato do referido contexto. O registro, por sua vez, informa o texto no contexto imediato, o de situação. O nosso objeto de investigação é o registro acadêmico reflexivo realizado na escrita do gênero relatório por alunos-mestre. O registro é compreendido como "variedade de uma língua envolvida em diferentes contextos de uso: formal ou casual, técnico ou não técnico, mais aberto ou mais fechado" (MATTHIESSEN; HALLIDAY, 2009, p. 81). Nessa perspectiva, "texto é a dupla realização de tipos de contexto e da promulgação do que é relevante a membros da cultura em situações" (EGGINS; MARTIN, 1997, p. 251).

\footnotetext{
${ }^{6} \mathrm{Na}$ LSF, os gêneros são, usualmente, compreendidos como "diferentes formas de usar a língua para alcançar diferentes tarefas culturalmente estabelecidas, textos de diferentes gêneros são textos que possibilitam o alcance de diferentes propósitos na cultura". Esses propósitos motivam a organização da estrutura textual em etapas ou estágios (EGGINS; MARTIN, 1997, p. 236). Para mais detalhes sobre a teoria de gêneros na LSF, consultar Martin (2012[1997], Martin e Rose (2009), Silva e Espindola (2013).
} 
O estrato do registro recebe mais destaque na LSF. Isso acontece porque "na interação instaurada no contexto de situação, podemos observar mais diretamente o conteúdo da ação social (campo), o envolvimento dos participantes (relações) e a forma de organização da língua (modo)" (SILVA; ESPINDOLA, 2013, p. 274). Esse conteúdo semântico se manifesta por meio do texto, que é o objeto de estudo na LSF com foco na oração, pois a análise gramatical é feita a partir da oração, mas sempre levando em consideração o texto e, claro, o contexto sociocultural que o envolve. ${ }^{7}$ Conforme detalhado na seção seguinte, os discursos de campo, relação e modo são as variáveis do contexto de situação, diretamente ligadas às metafunções ideacional, interpessoal e textual, respectivamente, representados na Figura 01.

\subsection{Gramática da oração: componente experiencial}

Para sintetizar o funcionamento da linguagem na abordagem sistêmico-funcional, considerando os estratos localizados "acima" e "abaixo", reproduzimos no Quadro 01 as relações estabelecidas entre as variáveis de registro, as metafunções da linguagem e os sistemas gramaticais responsáveis pela realização dessas últimas.

\footnotetext{
${ }^{7}$ De acordo com Halliday e Matthiessen (2014, p. 10), "a oração é a unidade central de processamento na léxico-gramática - no sentido específico de que é na oração que significados de diferentes tipos são mapeados dentro de uma estrutura gramatical integrada".
} 


\section{QUADRO 01}

Síntese teórica: registro e metafunções da linguagem ${ }^{8}$

\begin{tabular}{|c|c|c|}
\hline $\begin{array}{c}\text { CONTEXTO DE SITUAÇÃO } \\
\text { - REGISTRO } \\
\text { (MATTHIESSEN; HALLIDAY, 2009, } \\
\text { p. } 88 \text { ) }\end{array}$ & $\begin{array}{l}\text { METAFUNÇÃO DA LINGUAGEM } \\
\text { (MATTHIESSEN; HALLIDAY, 2009, } \\
\text { p. } 53 \text { e 54) }\end{array}$ & $\begin{array}{c}\text { SISTEMA } \\
\text { GRAMATICAL }\end{array}$ \\
\hline $\begin{array}{l}\text { (1) discurso de campo: "concerne ao } \\
\text { que acontece - os processos sociais } \\
\text { e os domínios de assunto criado } \\
\text { pela linguagem na realização desses } \\
\text { processos sociais". }\end{array}$ & $\begin{array}{l}\text { (1) ideacional: corresponde aos recursos } \\
\text { gramaticais responsáveis pela construção } \\
\text { da experiência humana no mundo exterior } \\
\text { que nos rodeia ou, até mesmo, no mundo } \\
\text { interior. }\end{array}$ & TRANSITIVIDADE \\
\hline $\begin{array}{l}\text { (2) discurso de relações: "concerne a quem } \\
\text { participa - os papéis sociais e relações } \\
\text { desses que participam da interação e } \\
\text { os papéis de fala e relações criadas pela } \\
\text { linguagem na realização desses papéis } \\
\text { sociais e relações". }\end{array}$ & $\begin{array}{l}\text { (2) interpessoal: corresponde aos recursos } \\
\text { gramaticais responsáveis pela manifestação } \\
\text { das relações sociais instauradas entre } \\
\text { os participantes da interação, falante e } \\
\text { destinatário. }\end{array}$ & MODO \\
\hline $\begin{array}{l}\text { (3) discurso de modo: "concerne a qual } \\
\text { papel a linguagem exerce no contexto } \\
\text { - sua distância desses envolvidos de } \\
\text { acordo com o meio (falado, escrito } \\
\text { e várias categorias mais complexas) } \\
\text { e canal (face a face, telefônico, } \\
\text { etc.), sua complementaridade com } \\
\text { outros processos sociais (de auxiliar } \\
\text { a constitutivo), e sua contribuição } \\
\text { retórica (didática, instrutiva, persuasiva } \\
\text { e outras)". }\end{array}$ & $\begin{array}{l}\text { (3) textual: é responsável por sentidos } \\
\text { desencadeados pela organização de } \\
\text { recursos gramaticais no texto, de maneira } \\
\text { que a distribuição dos elementos na } \\
\text { oração subsidie sentidos expressos pelas } \\
\text { metafunções previamente focalizadas, } \\
\text { num contexto situado. }\end{array}$ & TEMA \\
\hline
\end{tabular}

De acordo com o Quadro 01, a metafunção ideacional está relacionada à variável de discurso de campo e subdivide-se nos componentes experiencial e lógico. Realizado pelo sistema de TRANSITIVIDADE, o componente experiencial "oferece uma teia de opções inter-relacionadas para representar diferentes tipos de experiência - nossa experiência do mundo material, do mundo dentro de nossa consciência, do mundo de simbolização, e assim por diante" (MAT'THIESSEN; HALLIDAY, 2009, p. 61). Nas palavras de Eggins (2004, p. 213), "quando olhamos para a metafunção experiencial, nós estamos olhando para a gramática da oração como representação". Diferentemente da gramática tradicional, em que a transitividade referese à relação dos verbos e seus complementos, na abordagem sistêmicofuncional, a TRANSITIVIDADE é um sistema de descrição da oração

${ }^{8}$ Quadro expositivo reproduzido de Silva (2014b, p.1995). 
gramatical, composta por processos (formas verbais), participantes (formas nominais) e eventuais circunstâncias (formas adverbiais). ${ }^{9}$ Em outras palavras, os significados semiotizados na oração são marcados, respectivamente, pelas respostas às seguintes perguntas: o que se passa; quem faz o quê; onde, quando, como, por quê, etc.

Os diferentes processos passíveis de escolha pelo enunciador são responsáveis pela caracterização dos participantes, conforme sintetizado na Figura 02. Em outros termos, a escolha do processo, seja ele qual for, está associada à intenção, ao papel desempenhado pelo participante do processo representado. Esse último está ligado, necessariamente, a um participante, podendo haver também uma circunstância. Na LSF, são identificados três principais processos, material, mental e relacional, tendo como secundários outros três, comportamental, verbal e o existencial (cf. EGGINS, 2004; HALLIDAY; MATTHIESSEN, 2014; THOMPSON, 2014).

Na próxima seção deste artigo, os complexos oracionais focalizados são constituídos por orações primárias mentais, responsáveis pelo acionamento das demais orações do complexo, identificadas como secundárias. Durante a análise linguística dos documentos selecionados, somos desafiados a enfatizar os significados construídos a partir das escolhas léxico-gramaticais nos sistemas ou redes semânticas disponíveis na língua, minimizando o enfoque na identificação e classificação de elementos gramaticais com nomenclaturas linguísticas de referência. Na Figura 02, reproduzimos o sistema de escolha dos processos e dos participantes da oração, representados por Silva (2014, p. 81).

\footnotetext{
${ }^{9}$ Nos termos de Halliday e Matthiessen (2014, p. 10), "a perspectiva afasta-se da estrutura para consideração de gramática como sistema, permitindo-nos mostrar a gramática como recurso de produção de sentido e descrever categorias gramaticais pela referência ao que elas significam. Esta perspectiva é essencial se a análise gramatical for um modo perspicaz de entrada no estudo de discurso".
} 


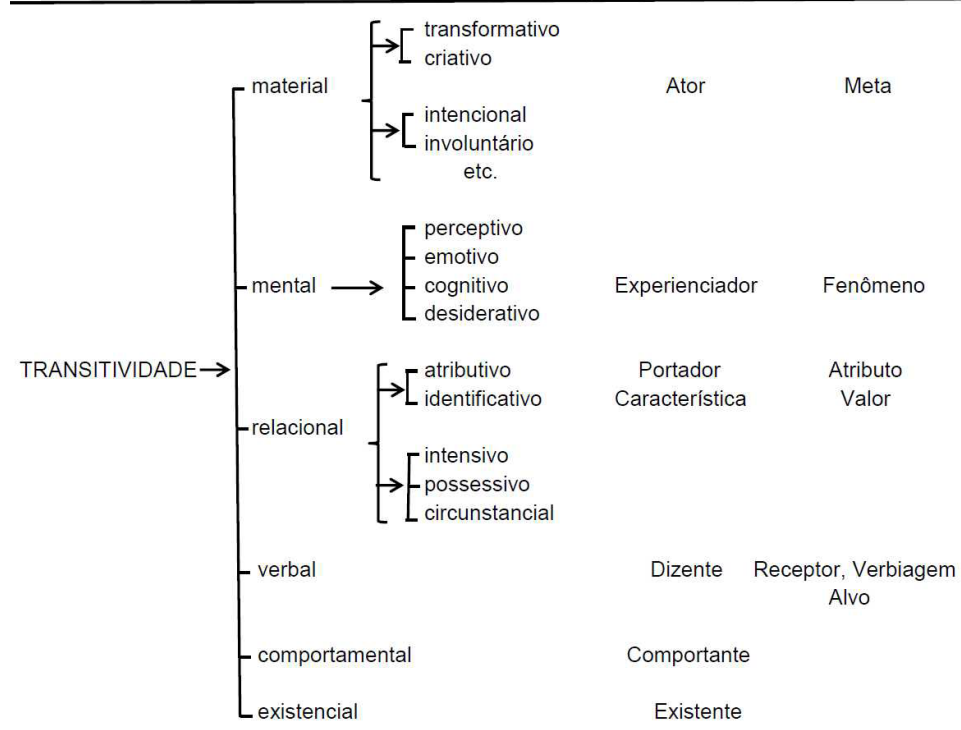

FIGURA 02: Processos e participantes no sistema de TRANSITIVIDADE

Dado o estágio da síntese teórica apresentada, podemos complexificar a concepção de linguagem assumida no início desta seção, considerando a seguinte ponderação reproduzida a partir de Matthiessen e Halliday (2009, p. 41):

Nós usamos linguagem para interagirmos uns com os outros, para construir e manter nossas relações interpessoais e a ordem social que se encontra por trás delas; e, fazendo isso, nós interpretamos e representamos o mundo para os outros e para nós mesmos. A linguagem é uma parte natural do processo de vivência; ela é também usada para "armazenar" a experiência pessoal e coletiva construída no curso desse processo. Ela é (entre outras coisas) uma ferramenta para representar conhecimento ou para observá-lo em termos de linguagem para construção de significado.

Conforme explicitado previamente, nosso enfoque recai sobre os componentes experiencial e lógico da metafunção ideacional, mesmo considerando o caráter multifuncional da linguagem na LSF. A compreensão do funcionamento desses componentes na escrita reflexiva profissional justifica nosso interesse em focalizá-los. Ainda são pouco estudados no 
contexto acadêmico brasileiro, ficando o enfoque das demais metafunções para outras pesquisas. Nesse sentido, torna-se desnecessário apresentar explicações detalhadas das metafunções interpessoal e textual, até porque esta revisão teórica se estenderia muito mais, o que não é possível para as dimensões de um artigo científico.

$\mathrm{Na}$ seção seguinte, atentamos de forma mais profunda para o componente lógico, unidade de referência da análise linguística apresentada: "a metafunção lógica nos permite produzir configurações mais complexas em que duas ou mais orações são agrupadas formando unidades maiores" (THOMPSON, 2014, p. 185).

\subsection{Complexo oracional: componente lógico}

$\mathrm{Na}$ metafunção ideacional, o componente lógico corresponde à articulação de sintagmas, grupos ou orações gramaticais. Nesta pesquisa, nosso enfoque recai especialmente sobre a organização do complexo oracional, logo, sobre a forma como as orações são interligadas. Este componente é realizado pelo sistema TÁTICO, por meio das taxes (parataxe e hipotaxe), e pelo sistema LÓGICO-SEMÂNTICO. O sistema TÁTICO descreve o tipo de interdependência entre as orações, que pode ocorrer por parataxe (representada nas análises por números), quando as orações ligadas possuem status gramatical de igualdade; e por hipotaxe (representada nas análises pelo alfabeto grego), quando há relação entre uma oração dependente e uma dominante. A noção de dependência está atrelada ao fenômeno linguístico em que uma oração ocupa a posição e a função de um elemento gramatical constitutivo de outra oração (HALLIDAY; MATTHIESSEN, 2014; EGGINS, 1994).

Conforme sintetizado no Quadro 02, Halliday e Matthiessen (2014, p. 442) classificam as orações como primárias ou secundárias: “a primária é a oração que inicia numa relação paratática, e a oração dominante numa hipotática; a secundária é a oração que continua numa relação paratática e a oração dependente numa hipotática”. 
QUADRO 02

Classificação das orações no componente lógico da metafunção ideacional

\begin{tabular}{|c|c|c|}
\hline TAXES & PRIMÁRIA & SECUNDÁRIA \\
\hline Parataxe & 1 (iniciando) & 2 (continuando) \\
\hline Hipotaxe & $\alpha$ (dominante) & $\beta$ (dependente) \\
\hline
\end{tabular}

O sistema LÓGICO-SEMÂNTICO “descreve a semântica das relações, os modos como as orações são construídas independente ou dependente nos significados experienciais das orações que eles relatam" (EGGINS, 2004, p. 270). Este sistema corrobora nossa construção das representações das coisas no mundo, o que, de alguma forma, acontece pela ampliação gramatical do próprio sistema de TRANSITIVIDADE e, consequentemente, do fluxo de conteúdo semântico-discursivo passível de interpretação na materialidade textual. Em outras palavras, as coisas no mundo são representadas por meio da oração gramatical e, quando articulamos mais de uma oração, estamos complexificando nossa compreensão ou representação num dado contexto sociocultural.

A relação lógico-semântica ocorre por meio da projeção e da expansão. De acordo com Halliday e Matthiessen (2014, p. 508), a projeção corresponde à "articulação lógico-semântica onde uma oração funciona não como uma representação não linguística direta da experiência, mas como uma representação de uma representação linguística". Em outros termos, a projeção corresponde a reenunciação de uma locução ou ideia responsável por uma dada representação do mundo exterior ou interior. A representação linguística projetada pode ser originária do próprio responsável pela projeção ou de outrem. Por ser motivada pelo gênero textual, a projeção possibilita "atribuir fontes num relato de notícia, representar perspectivas no discurso científico, construir diálogo em narrativas, emoldurar perguntas em conversação" (HALLIDAY; MATTHIESSEN, 2014, p. 509). Há dois tipos de projeção: uma oração primária projeta uma secundária por meio da enunciação de uma locução (representada nas análises por aspa dupla: "); e da enunciação de uma ideia (representada nas análises por aspa simples: '). No primeiro tipo, temos "uma representação do conteúdo de uma oração verbal"; no segundo, "uma representação do conteúdo de uma oração mental” (HALLIDAY; MATTHIESSEN, 2014, p. 509). ${ }^{10}$

${ }^{10}$ Para mais detalhes sobre a projeção no gênero relatório de estágio, consultar os seguintes trabalhos: Melo e Gonçalves (2014); Melo (2015). 
$\mathrm{Na}$ expansão, a oração secundária é expandida por meio de elaboração (representada pelo sinal de igualdade: $=$ ), extensão (representada pelo sinal de adição: +) e intensificação (representada pelo sinal de multiplicação: $x$ ) (HALLIDAY; MATTHIESSEN, 2014). ${ }^{11} \mathrm{O}$ sistema de realização do complexo oracional está sintetizado na Figura 03. ${ }^{12}$

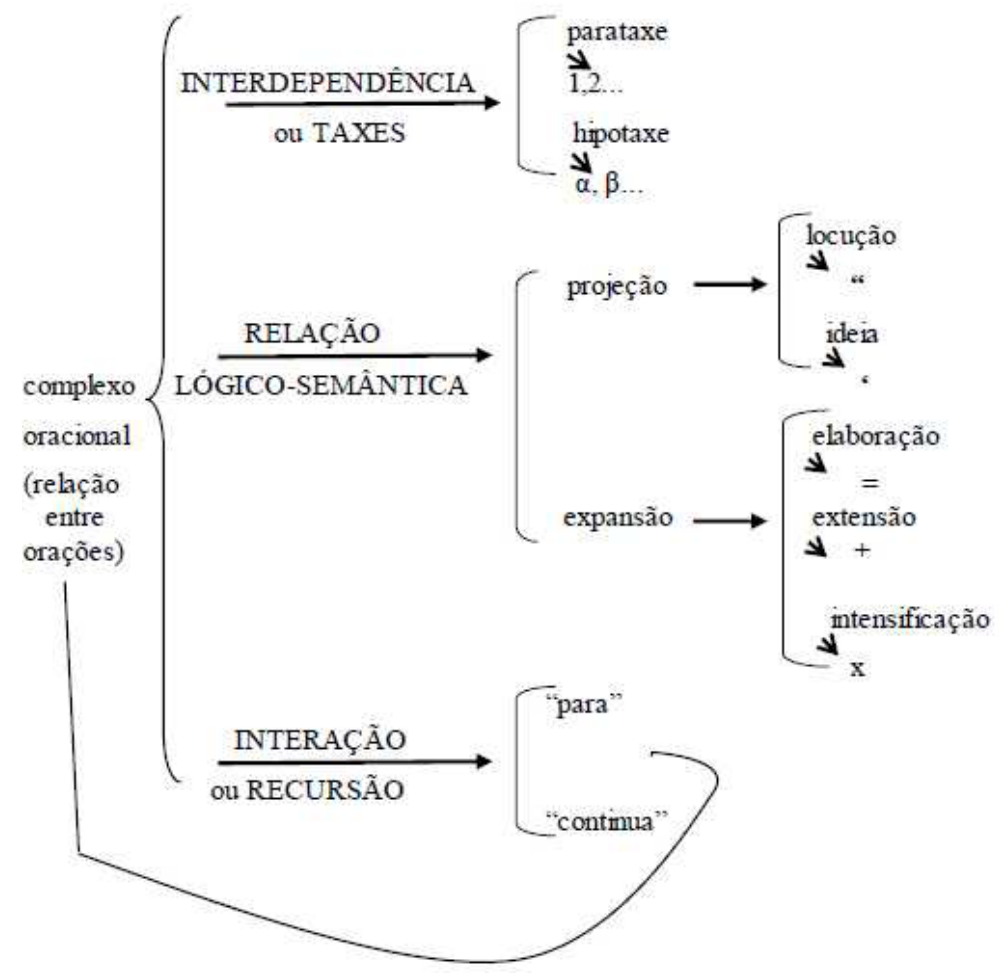

FIGURA 03: Sistema de realização do complexo oracional

Os sistemas de TAXES e LÓGIGO-SEMÂNTICO se realizam simultaneamente e são independentes. As orações gramaticais podem ser projetadas por parataxe ou hipotaxe, ambas podem projetar locução ou ideia

\footnotetext{
${ }^{11}$ Ressaltamos ainda que, nas análises linguísticas dos complexos oracionais, utilizamos três barras verticais (| | |) para delimitar os limites do complexo oracional; duas barras verticais (| |) para delimitar a fronteira entre as orações; e colchetes ([]) para delimitar os limites das orações encaixadas (HALLIDAY; MATHIESSEN, 2014).

${ }^{12}$ A Figura 3 foi elaborada a partir das representações de Eggins (2004, p. 259) e de Matthiessen e Halliday (2009, p. 71).
} 
conforme a configuração gramatical de realização do que, tradicionalmente, compreendemos por discurso direto (parataxe) e indireto (hipotaxe). Da mesma forma, a expansão pode ocorrer tanto por hipotaxe como por parataxe. Dependendo do sentido instaurado na articulação entre orações por expansão, a abordagem sistêmico-funcional identificou três modos de expansão (EGGINS, 2004, p. 259; HALLIDAY; MATTHIESSEN, 2014, p. 444):

1. Elaboração: a oração primária tem seu significado elaborado pela oração secundária, especificando ou descrevendo-a. Pode ser realizada pela exposição, detalhamento, exemplificação ou clarificação.

2. Extensão: a oração primária estende seu significado acrescentando algo novo, adicionando algum elemento novo, apresentando uma exceção ou oferecendo uma alternativa;

3. Intensificação: a oração primária tem seu significado intensificado pela oração secundária, isso pode ocorrer por diferentes maneiras: tempo, modo, lugar, causa ou condição.

Conforme apresentado na próxima seção, consideramos as orações primárias mentais como referência para identificação dos complexos oracionais investigados na escrita acadêmica reflexiva. Utilizamos o componente experiencial para analisar as escolhas dos participantes e dos processos nas orações primárias mencionadas. Utilizamos o componente lógico para analisar especialmente as orações secundárias: orações paratáticas extensivas, utilizadas como complementos de orações mentais perceptivas hipotáticas, funcionam como orações encaixadas; ${ }^{13}$ e orações hipotáticas projetadas por orações mentais cognitivas. Interessa-nos investigar as representações construídas dentro da consciência dos alunos-mestre na experiência vivenciada por eles no estágio supervisionado obrigatório, realizado no intercontexto da escola básica e da universidade.

\footnotetext{
${ }^{13}$ Conforme esclarecido por Thompson (2014, p. 191), “as orações encaixadas não formam complexos oracionais, pois funcionam como constituintes em outras orações; e, portanto, as categorias de hipotaxe e parataxe não se aplicam às encaixadas como um conjunto (apesar de poder ocorrer parataxe e hipotaxe dentro da encaixada - ou seja, um complexo oracional encaixado)".
} 


\section{Reflexões construídas na escrita acadêmica}

Conforme informado na introdução deste artigo, para a produção desta pesquisa, o principal corpus investigado foram 07 (sete) relatórios escritos produzidos por alunos-mestre na primeira disciplina de estágio supervisionado, integrante de uma sequência de três disciplinas ofertadas em semestres consecutivos, numa Licenciatura em Matemática. Os relatórios de estágio são identificados como memoriais de estágio conforme orientação do próprio formador, ainda que apresentem uma estrutura textual esquemática característica do que compreendemos por relatórios ou portfólios, produzidos ao final das disciplinas de estágio nas licenciaturas: agradecimento; introdução; estrutura física; aspectos didático-pedagógicos (projetos da escola, projetos de matemática); formação e prática educativa matemática (formação docente e metodologia de ensino, prática docente: descrição e análise, indice de aprovação/reprovação); projeto de intervenção; conclusões e considerações finais; referencial bibliográfico (cf. SILVA, 2012a). Mesmo recebendo uma denominação diferente, os textos aqui investigados se caracterizam como relatórios de estágio, na perspectiva teórica assumida nesta pesquisa. Eles fazem parte do acervo do Centro Interdisciplinar de Memória dos Estágios das Licenciaturas (CIMES), sediado no Câmpus Universitário de Araguaína, pertencente à Universidade Federal do Tocantins (UFT).

A identificação dos textos como memoriais cria-nos a expectativa de encontrar uma escrita mais subjetiva, o que não se confirma desde os tópicos selecionados para organização textual, conforme elencados no parágrafo anterior. Sabemos que houve um esforço do formador para se distanciar da tradição acadêmica burocrática e técnica do uso de relatórios como instrumento de avaliação ao final das disciplinas de estágio obrigatório, mas esse modelo ainda parece resistir:

A questão está em se distanciar de um procedimento meramente técnico e burocrático ou meramente avaliativo (ou seja, unicamente como instrumento de avaliação da disciplina Estágio), para um momento de reflexão crítica da práxis docente, curta, mas intensamente (até certo ponto obviamente) vivenciada no estágio. (enunciado do formador em interação por e-mail)

A prática de reescrita do relatório também foi encaminhada pelo formador, mas houve bastante resistência por parte dos alunos-mestre, que, certamente, não eram familiarizados a lidar com a escrita como processo, 
diferentemente do tratamento da escrita como produto. ${ }^{14} \mathrm{O}$ professor de Matemática também precisa focalizar práticas de leitura e escrita no cotidiano da sala de aula, portanto, a inserção ou familiarização desses alunos-mestre em/com práticas de reescrita é bastante significativa para o letramento acadêmico e, até mesmo, para o letramento do professor exigido no local de trabalho, ambos em construção na licenciatura (cf. SILVA, 2012b).

A observação realizada por Lea e Street (2014, p. 484) a respeito do letramento acadêmico de estudantes de diferentes disciplinas, no contexto universitário britânico, parece aplicável ao brasileiro, mesmo considerando a enorme diversidade de acadêmicos constitutiva de um país com dimensões continentais: "alunos de disciplinas de ciência parecem estar menos familiarizados com prosa de longa duração, contudo estão adaptados a leiaute estruturado e emprego de signos visuais". Os autores complementam: "Estudantes de ciências sociais têm mais trabalho escrito para fazer em sua prática escolar, mas não necessariamente conseguem diferenciar traços do modo escrito daqueles do falado e do leiaute visual". ${ }^{15}$

\footnotetext{
${ }^{14}$ Nas próprias palavras do formador, atuante na área da educação matemática: "Desde 2010, tenho orientado os alunos a fazerem as correções e entregar uma nova versão corrigida, seja na versão impressa, antigamente, seja na versão digital, atualmente. Porém, pouquíssimos alunos se preocupam em fazer tal tarefa "extra". Desde 2013 venho solicitando, formal ou informalmente, que os alunos procurem entregar uma versão inicial do relatório, mas são poucos que conseguem ou se preocupam em fazêlo. Outro procedimento que sempre adotei foi de destinar na carga horária teórica da disciplina, alguns encontros específicos para orientação e acompanhamento da elaboração do relatório final. Enfim, muitos dos trabalhos entregues contêm erros dos mais diversos, desde formatação, passando pelos erros de português, até erros no sentido de não ter seguido minhas orientações quanto ao conteúdo do memorial. Mas, quando estes erros estão num grau, a meu ver, excessivamente predominantes a ponto de comprometer a produção em si, o estagiário é solicitado obrigatoriamente a refazer o trabalho" (Interação entre pesquisadores e formador por e-mail).

${ }^{15}$ Em pesquisa anterior sobre atividades escolares envolvendo a produção escrita, propostas por alunos-mestre durante os estágios de regência nas Licenciaturas em Geografia, História e Matemática, desenvolvida no mesmo contexto de formação inicial de professores do curso focalizado neste artigo, Tavares (2011) mostrou, ao analisar relatórios de estágio, que, nos documentos da Matemática, são praticamente inexistentes propostas de atividades que demandem a realização de práticas convencionais de escrita pelos alunos da escola básica, durante as aulas ministradas pelos alunos-mestre. Nesse sentido, temos indícios de que práticas de escrita não sejam privilegiadas na licenciatura aqui focalizada.
} 
Quando nos referimos aos relatórios da Licenciatura em Matemática como corpus principal desta pesquisa, sinalizamos para a existência de documentos secundários investigados, a saber: outros sete (07) relatórios produzidos em cada primeira disciplina de estágio obrigatório das Licenciaturas em Língua Portuguesa e em Língua Inglesa, os quais constituem um corpus mais amplo de pesquisa com vinte e um (21) relatórios produzidos nos três cursos focalizados. A existência de apenas sete (07) relatórios numa turma da Licenciatura em Matemática determinou nossa opção em trabalhar com a mesma quantidade de documentos dos outros dois cursos. Para tanto, escolhemos os sete primeiros arquivos com relatórios digitalizados nas pastas das outras duas licenciaturas.

Os excertos reproduzidos como exemplos das análises dos dados são identificados pelo nome da seção original do relatório, licenciatura de origem e número identificador do relatório. Os três relatórios que integram os três agrupamentos das licenciaturas (Língua Portuguesa, Língua Inglesa e Matemática) foram enumerados de um (1) a sete (7). Os exemplos foram transcritos conforme o original. A não realização de correções linguísticas nos permite evidenciar dificuldades de escrita enfrentadas pelos alunosmestre. Em alguns momentos, essas dificuldades nos levaram a acrescentar algumas formas gramaticais para auxiliar na compreensão da análise linguística realizada. Tais acréscimos são utilizados entre chaves $(\{\})$.

\section{1 Ênfase no componente experiencial da escrita acadêmica}

Inicialmente, realizamos uma análise comparativa entre os documentos das três licenciaturas mencionadas, identificando os complexos oracionais em que a oração primária fosse caracterizada como mental. Na Figura 04, os gráficos mostram a menor ocorrência de processos mentais perceptivos e cognitivos nos relatórios da Licenciatura em Matemática, totalizando 39 ocorrências (22,67\%). Nos textos dessa licenciatura, a significativa diferença entre as ocorrências dos processos perceptivos e cognitivos está representada de forma mais explícita no gráfico da Figura 05. Nas Licenciaturas em Língua Portuguesa e em Língua Inglesa, identificamos, respectivamente, um total de $58(33,7 \%)$ e $75(43,6 \%)$ processos mentais. Esses resultados quantitativos revelam um registro reflexivo menos intenso nos relatórios da Licenciatura em Matemática, o que pode ser justificado pela própria estrutura textual esquemática nos documentos de cada curso. Nos escritos das Licenciaturas 
em Letras, por exemplo, a reflexão mais expressiva pode ser motivada pela existência de uma seção no relatório denominada relato reflexivo.

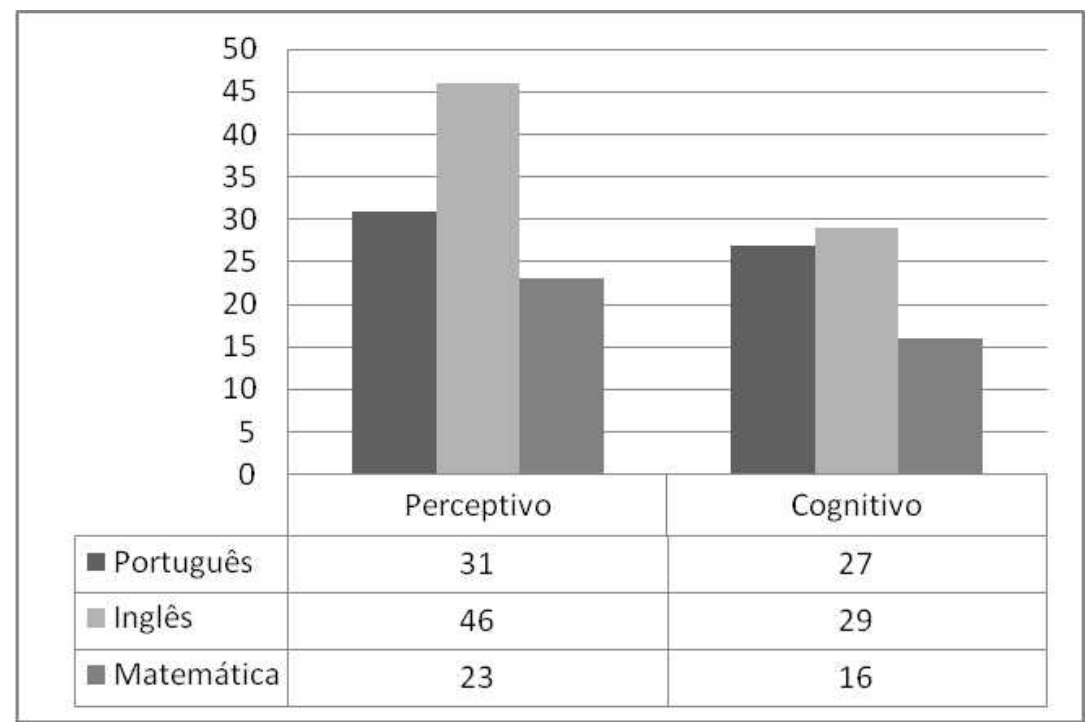

FIGURA 04: Comparação de processos perceptivos e cognitivos nas licenciaturas

Outro aspecto a destacar nos gráficos da Figura 4 é a maior ocorrência nos textos de todas as licenciaturas dos processos mentais perceptivos $(58,1 \%)$, realizados pelas formas verbais que indicam impressões de coisas ou de fenômenos experienciados na escola básica. Nos relatórios da Licenciatura em Língua Inglesa, encontramos maior desequilíbrio entre os usos de processos perceptivos e cognitivos. A ocorrência desse último processo nos textos investigados é menor (41,8\%), quando comparada aos primeiros.

Nossos cinco sentidos são responsáveis pelas representações construídas pelos perceptivos. Nos relatórios investigados, esses processos trazem representações de impressões dos alunos-mestre, dos fenômenos experienciados de forma mais imediata nas aulas observadas. São realizados em passagens textuais mais descritivas. Muitas dessas descrições possuem um significativo valor argumentativo, pois resultam do trabalho intelectual e crítico dos alunos-mestre, daí a relevância desses processos na construção da escrita reflexiva como instrumento mediador na formação do profissional crítico. Os processos cognitivos remetem a um trabalho intelectual mais elaborado. Expressam pensamento, compreensão, conjetura, ou seja, trazem 
um ponto de vista ou posicionamento crítico já elaborado a respeito de experiências vividas.

No Quadro 03, elencamos os processos mentais perceptivos utilizados pelos alunos-mestre nos relatórios. Seguindo a mesma tendência dos resultados apresentados nos gráficos da Figura 04, identificamos a menor diversidade de processos na Licenciatura em Matemática. Esse fato é diferente do que acontece nas outras duas licenciaturas, especialmente no tocante aos processos cognitivos que apresentam uma diversidade maior de ocorrência nos relatórios da Licenciatura em Língua Portuguesa, mesmo que a frequência desses elementos gramaticais seja maior nos documentos da Licenciatura em Língua Inglesa, conforme visto na Figura 04. A ocorrência das subcategorias de processo mental desiderativo (indica desejo) e emotivo (indica emoção) é bastante pontual. Quando utilizados, encontramos apenas uma ocorrência por licenciatura focalizada. Esses processos não são analisados neste artigo.

QUADRO 03

Processos perceptivos e cognitivos identificados nos relatórios investigados

\begin{tabular}{|l|l|l|l|}
\hline \multirow{2}{*}{ LICENCIATURA } & \multicolumn{1}{|c|}{ Português } & \multicolumn{1}{|c|}{ Inglês } & \multicolumn{1}{|c|}{ Matemática } \\
\hline PROCESSO & $\begin{array}{l}\text { Perceptivo } \\
\text { evidenciar; identificar; } \\
\text { notar; observar; perceber; } \\
\text { ver; verificar }\end{array}$ & $\begin{array}{l}\text { notar; observar; perceber; } \\
\text { ver; verificar }\end{array}$ & $\begin{array}{l}\text { constatar; notar; observar; } \\
\text { perceber; ver }\end{array}$ \\
\hline Cognitivo & $\begin{array}{l}\text { acreditar; assumir; } \\
\text { averiguar; compreender; } \\
\text { concluir; concordar; } \\
\text { considerar; crer; pensar; } \\
\text { perceber; refletir; resolver; } \\
\text { saber }\end{array}$ & $\begin{array}{l}\text { achar; acreditar; } \\
\text { compreender; concluir; } \\
\text { concordar; crer; pensar; } \\
\text { refletir; saber; }\end{array}$ & $\begin{array}{l}\text { achar; acreditar; aprender; } \\
\text { assumir; concluir; despertar; } \\
\text { saber }\end{array}$ \\
\hline
\end{tabular}

A classificação dos processos elencados no Quadro 03 nem sempre é realizada de forma simples. A análise dos dados revelou que o processo perceber pode ser caracterizado como perceptivo ou cognitivo, dependendo do uso ou da leitura realizada, daí também a relevância da consideração de aspectos contextuais durante o exame dos dados. Entre os perceptivos, identificamos os processos perceber, observar e notar como formas gramaticais mais recorrentes. Entre os cognitivos, identificamos o processo acreditar 
como forma mais recorrente, além do processo concluir como uso recorrente nas considerações finais dos relatórios.

No Exemplo 01, ilustramos perceber como processo cognitivo, diferentemente da compreensão mais comum da forma verbal como processo perceptivo. Essa última acepção parece bastante presa à forma dicionarizada do verbo, diferentemente da leitura contextualizada do processo em uso.

Exemplo 01 - Considerações finais

Pude refletir acerca do que eu poderia melhorar e mudar nas aulas que observei. Percebi que de fato é de suma importância que nos adequemos à realidade do aluno para assim incorporarmos em nossas aulas assuntos que tenha alguma relevância na vida dos mesmos. Percebi também que ser professor não é tarefa simples é necessário paciência, dedicação e acima de tudo amor pela sua profissão, pois as atitudes do educador influem na formação dos alunos. (Licenciatura em Língua Portuguesa - R3)

O excerto do Exemplo 01 foi reproduzido das considerações finais do relatório, quando o aluno-mestre demonstra esforço para apresentar um posicionamento próprio diante das experiências compartilhadas no relatório. Isso fica evidente no primeiro complexo oracional iniciado pela oração mental cognitiva projetante Pude refletir. Nessa oração, o finito Pude ganha relevância por exercer a função de tema interpessoal. Ou seja, é destacada a situação favorável ao aluno-mestre para refletir sobre a prática pedagógica no contexto universitário, o que, certamente, não era uma prática frequente em outras disciplinas da licenciatura. O uso desse modalizador é bastante recorrente nos dados analisados e é elucidado também no Exemplo 07.

No Exemplo 01, essa reflexão de fundo representada pelo alunomestre serve como âncora para enunciar os complexos oracionais seguintes: ambos iniciados pelo processo mental perceber, responsável por projetar orações em que são representadas ideias produzidas na mente do alunomestre como resultado das reflexões previamente realizadas. O significado apreendido dos usos do referido processo cognitivo assemelha-se ao valor semântico da formar verbal concluir. No excerto em evidência, Perceber projeta uma ideia, diferentemente da funcionalidade constitutiva do processo perceptivo original, que não projeta. No último caso, a ideia é diretamente motivada a partir da situação experienciada.

Nos relatórios das três licenciaturas, o aluno-mestre é representado como Experienciador mais recorrente nas orações primárias mentais, conforme as reproduzidas no Exemplo 01. Os gráficos justapostos na 
Figura 05 apresentam a análise quantitativa e comparativa entre os três agrupamentos de relatórios, considerando os principais atores sociais representados como Experienciadores dos processos perceptivos e cognitivos identificados.
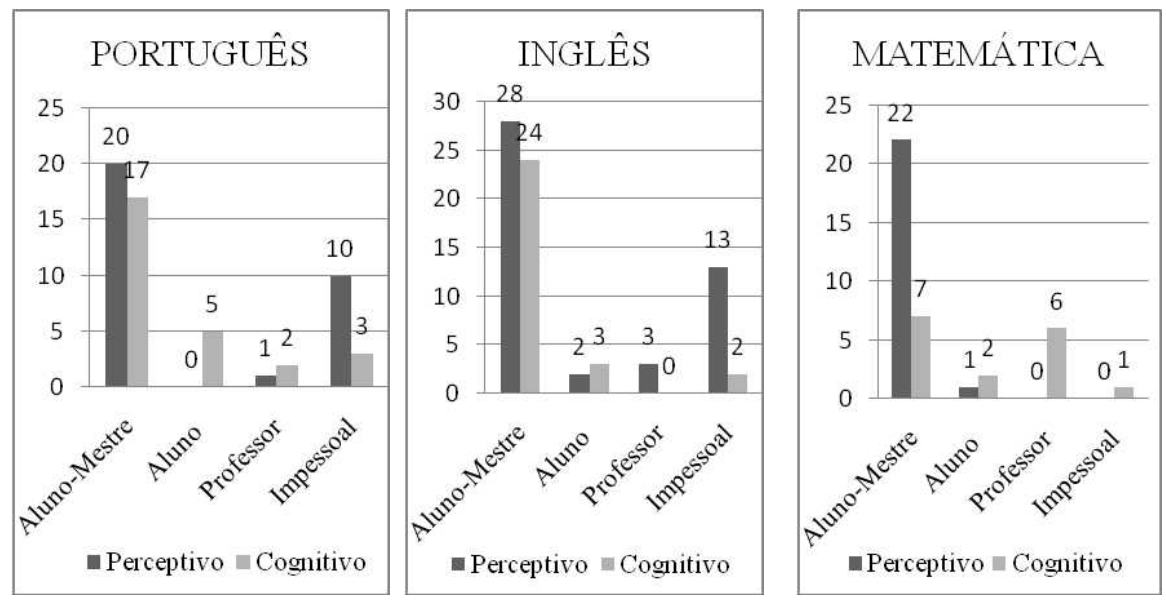

FIGURA 05: Processos e Participantes por Licenciaturas

O próprio gênero motiva a representação dos alunos-mestre como experienciadores mais recorrentes, pois os relatórios investigados trazem as experiências vivenciadas pelos alunos-mestre durante a observação de aulas na escola básica, conforme vimos no Exemplo 01. A ocorrência reproduzida no Exemplo 02, por sua vez, ilustra uma forma particularizada do alunomestre se autorrepresentar no registro acadêmico reflexivo. Ao utilizar a forma nominal o acadêmico das licenciaturas, o autor se utiliza do processo mental perceptivo na terceira pessoa (percebe), instaurando um distanciamento da escrita produzida. Provavelmente, por se tratar da parte final do texto (Considerações finais), o aluno-mestre parece se expressar representando uma coletividade, os professores em formação inicial, apresentando impressões que ecoam vozes dessa coletividade. Esse distanciamento ocorreu no documento da Licenciatura em Matemática, identificado como Memorial de Estágio Supervisionado, o que, conforme pontuamos previamente, demandaria uma escrita mais subjetiva, ou seja, com mais marcas linguísticas opinativas ou avaliativas. 
Os gráficos da Figura 05 mostram ainda algumas ocorrências dos alunos e dos professores da escola básica como Experienciadores dos processos mentais nas orações primárias dos complexos identificados. Esse último fenômeno acontece normalmente quando o aluno-mestre reporta algum pensamento explicitado por alunos ou professores da escola básica a partir de diálogos instaurados durante as atividades de estágio na escola. A baixa ocorrência desses participantes como Experienciadores da oração primária pode ser um indício de uma interação pouco significativa entre tais atores sociais e alunos-mestre durante os estágios obrigatórios. Nesse sentido, esses complexos oracionais ocorrem vinculados a projeções de locuções, realizadas por meio de processos verbais. Esses últimos casos são ilustrados nos dois excertos seguintes, ambos da Licenciatura em Matemática.

Exemplo 03 - Índice de aprovação/reprovação na disciplina Matemática

E tudo isso pude confirmar ao entrevistar os professores A e B das turmas. Eles acreditam também que existe um fracasso da matemática no ensino Fundamental e Médio esse fracasso aparece exatamente na aprendizagem e no interesse desses alunos, que hoje em dia não se preocupam em estudar. (Licenciatura em Matemática - R2)

O Exemplo 03 mostra que, a partir de entrevistas com professores, o aluno-mestre confirma as próprias impressões a respeito das crenças negativas dos alunos do ensino básico sobre a Matemática. Conforme discutido no relatório, essas crenças são construídas ao longo da vida escolar dos alunos, o que seria provocado, em especial, por aulas ministradas com pouca atratividade. ${ }^{16}$ Parte dessas impressões é compartilhada pelos

\footnotetext{
${ }^{16}$ No parágrafo que antecede o excerto reproduzido no Exemplo 3, é afirmado que: "Se o ensino da matemática fosse tratado com as necessidades diárias e a realidade vivida, ele se tornaria mais interessante e os assuntos poderiam ser apresentados de uma maneira mais clara e significativa e assim proporcionaria motivação e momentos de prazer com isso teriam grandes resultados significativos nas escolas, a matemática não seria vista como a pior matéria escolar" (R2 - Licenciatura em Matemática: Índice de aprovação/reprovação na disciplina Matemática).
} 
professores entrevistados, conforme projeção realizada com o uso do processo mental cognitivo (acreditam), tendo os professores como Experienciadores. É projetada uma representação de fracasso do ensino da disciplina escolar atrelado ao aprendizado e interesse dos alunos. Ao projetar a ideia sobre o fracasso escolar compartilhada pelos entrevistados, o aluno-mestre não apresenta informações a respeito do ponto de vista do próprio professor sobre sua responsabilidade diante do cenário negativo experienciado. Talvez, o professor não tenha se atentado a fazer uma reflexão sobre a própria responsabilidade diante da situação descrita.

Exemplo 04 - Caracterizações da turma e da sala de aula

Perguntei a ela se gosta de matemática, ela me disse que sim, gosta e sempre tenta aprender mais e se interessa a aprender os conteúdos novos, pois ela quer futuramente ingressar na em uma faculdade para cursar Administração e já sabe que para esse curso ela terá de estudar muita matemática. (Licenciatura em Matemática $-\mathrm{R} 2)$

No Exemplo 04, encontramos projeções de elocuções que representam um diálogo entre aluno-mestre e aluna da escola básica, durante o estágio de observação. No primeiro momento, o aluno-mestre é representado como Dizente da pergunta realizada à aluna (Perguntei). No segundo momento, a aluna é representada como Dizente e o aluno-mestre como Receptor da elocução (disse). O processo mental cognitivo sabe projeta uma ideia previamente compartilhada pela aluna com o aluno-mestre. Nesse sentido, a aluna é representada como Experienciadora do conteúdo projetado na oração secundária.

$\mathrm{Na}$ análise dos dados, ainda identificamos construções gramaticais impessoais, nas quais os experienciadores não são identificados explicitamente ou recuperáveis pelas desinências das formas verbais ou por retomadas nominais. Essas construções são realizadas pelos recursos gramaticais disponíveis na própria língua portuguesa, a exemplo das formas verbais flexionadas na terceira pessoa do plural sem sujeito gramatical explícito ou flexionadas na terceira pessoa do singular seguida pelo pronome se. As construções das formas verbais na voz passiva também são recorrentes nas representações com Experienciadores não identificados (cf. SILVA, 2014a). Outra construção gramatical que resulta na indeterminação do Experienciador é a construção projetante É + Modalizador (Adjetivo) + Processo, conforme ilustrado no Exemplo 05. 
Exemplo 05 - Índice de aprovação/reprovação na disciplina Matemática

É possível assumir que o sucesso do aluno na aprendizagem dos conteúdos matemáticos depende, em grande parte, da qualidade da mediação desenvolvida em sala de aula pelo professor. (Licenciatura em Matemática $-\mathrm{R} 2)$

O Exemplo 05 pertence ao início da mesma seção da qual reproduzimos o Exemplo 3. O excerto apresenta o que podemos denominar de tese a ser desenvolvida na seção. Traz um conteúdo que, usualmente, é tratado com bastante apreensão pelos alunos-mestre, pois focaliza o professor da escola básica como ator central no trabalho de mediação desencadeador da aprendizagem do aluno, podendo resultar num tipo de exposição indesejada do profissional que colabora diretamente para a realização do estágio obrigatório na escola. Provavelmente, esse tipo de conteúdo justifique a ausência de identificação explícita do Experienciador, bem como da modalização integrante da construção gramatical. Essa construção não é recorrente nos textos da Licenciatura em Matemática, diferentemente do que acontece nos documentos das Licenciaturas em Língua Portuguesa e Língua Inglesa, onde encontramos: foi possível diagnosticar, foi possivel identificar, é plausivel diz̧er. Uma variante dessa construção são as seguintes ocorrências: é percebivel; é perceptivel; é notável. Esses dois últimos casos pontuados merecem estudos particularizados em outro momento.

\section{2 Ênfase no componente lógico da escrita acadêmica}

Exemplificamos nos dois excertos seguintes os tipos de ocorrência regulares das orações paratáticas extensivas utilizadas como complementos de orações mentais perceptivas hipotáticas. A análise desses complexos oracionais revelou que as orações secundárias semiotizam descrições de cenas ou ambientes vivenciados pelos alunos-mestre no estágio, o que acontece pela justaposição de orações. Muitas vezes, tais descrições servem para ancorar a explicitação do posicionamento crítico do aluno-mestre, apresentado posteriormente por meio da projeção por processo cognitivo. 
| | $a$ Dentro da escola percebi || [【[ 1 $\beta$ que não vende guloseimas ||$+2 \beta\{q u e\}$ não é autorizado vendedores ambulantes, ||$+3 \beta$ \{que tem $\} 1$ sala de laboratório [/a qual não estava funcionando pois estava servindo de deposito para entrega de livros didáticos para os alunos $]]||+4 \beta\{q u e\}$ os computadores estava todos desmontados, [/sendo que foi necessário ir duas vezes a escola para conseguir entrar no laboratório na segunda vez encontrei só a sala aberta, não encontrei a pessoa responsável pela sala dos computadores estava todos desmontados, 77||$+5 \beta$ \{e que tem $\} 1$ biblioteca muito pequena para os alunos //se um professor for levar uma turma não caberá os mesmos todos, os professores também não freqüentam muito, pois só possui três mesas e poucas cadeiras e poucos livros para pesquisas, não tem ventilador o ar condicionado não esta funcionando, a localização da biblioteca não é um local de livre acesso. 7$]$ J]7 | | | (Licenciatura em Matemática - R2)

Esperávamos reflexões mais significativas na escrita dos relatórios da licenciatura focalizada, o que evidenciaria um esforço do alunomestre para compreender o que se passa por trás das ações vivenciadas no estágio obrigatório. No Exemplo 06, reproduzido da seção Estrutura e Funcionamento da Escola, o complexo oracional mental perceptivo (percebi) é utilizado para detalhar discursivamente a percepção do ambiente físico e do funcionamento da escola, observados a partir de um primeiro plano. Por meio da justaposição de orações paratáticas extensivas, figuras negativas são representadas pelo acréscimo de aspectos caracterizadores do ambiente descrito. Em outros termos, o espaço de realização do estágio obrigatório é construído pelas percepções apresentadas, informadas, inclusive, pelas ausências de serviços e artefatos necessários para uma prática de ensino produtiva. O aluno-mestre inicia uma reflexão, a partir do contexto escolar vivenciado, sobre como a infraestrutura da escola e a gestão podem dificultar o trabalho pedagógico desejado.

Exemplo 07 - Considerações finais

| | | a Pude observar || [ढ[ $\beta$ a 1 que os professores são ou estão desestimulados, || $\beta \times \beta 1[\llbracket[$ por culpa da sociedade $\beta=a 1$ que não dá o devido reconhecimento ||$\beta+\beta 1$ [[que esse profissional merece; ]] J]] ||$\beta$ $+21\{q u e\}$ a maioria dos alunos são desinteressados, ||$\beta+2+2$ muitas vezes desrespeitam o professor || $\beta+2+3$ e passam aula toda atrapalhando; ||$\beta+3 \alpha$ qque $\}$ o tempo para ministrar as aulas é curto, ||$\beta+3$ $=\beta$ o que não dá para abordar todo o conteúdo previsto naquela série ||$\beta+4\{$ e que $\}$ e muitas vezes a escola não oferece toda estrutura necessária para um bom processo de ensino-aprendizagem. | | |J7j] (Licenciatura em Matemática - R2)

No Exemplo 07, pertencente às Considerações finais do mesmo relatório de onde reproduzimos o excerto anterior, o aluno-mestre parece apresentar uma reflexão mais crítica a respeito do local de trabalho do professor. Certamente, essa criticidade justifica-se pelo excerto ter sido reproduzido da 
seção do relatório em que o aluno-mestre tende a explicitar mais claramente suas impressões sobre o estágio, daí a relevância dos quatro pontos destacados em cada uma das orações extensivas justapostas: professores desestimulados; alunos desinteressados; tempo curto das aulas; e estrutura escolar precária. Dada a elaboração representada na justaposição de argumentos, acreditamos que a oração primária, formada pelo finito na função de modalizador (Pude) e pelo processo perceptivo na função de predicador (observar) possui um valor semântico muito próximo ao que compreendemos por processo cognitivo, afinal, os referidos argumentos não resultam simplesmente da observação, mas, sim, de um trabalho intelectual mais intenso. Trata-se realmente de conclusões elaboradas na mente do aluno-mestre.

Os alunos-mestre devem compreender que realmente há possíveis e justificáveis razões para as situações de ensino observadas, daí a relevância do trabalho com/sobre a escrita do relatório estimular a reflexão ou rememoração em torno dessas situações. Para tanto, o formador tem um importante papel a desempenhar como mediador desse evento de letramento acadêmico capaz de catalisar inúmeras práticas escolares. A reflexão ou rememoração é evidenciada de forma mais intensa nas orações mentais cognitivas. Nesse sentido, nos últimos dois exemplos reproduzidos adiante, mostramos a funcionalidade das orações hipotáticas projetadas por orações mentais cognitivas.

\begin{tabular}{|c|}
\hline Exemplo 08 - Considerações finais \\
\hline 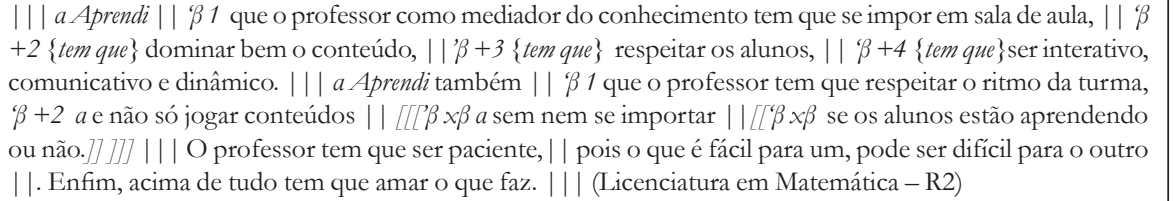 \\
\hline
\end{tabular}

O Exemplo 08 nos mostra evidências de que o aluno-mestre considera que o estágio realizado lhe permitiu "apreender como se dão as relações de trabalho" (GISI; MARTINS; ROMANOWSKI, 2009, p. 208), conforme esperado da referida disciplina na licenciatura. Nos dois complexos oracionais do Exemplo 08, encontramos o processo Aprendi na função de oração projetante. Mais uma vez, as representações construídas correspondem a conclusões elaboradas na mente do aluno-mestre a partir da vivência do estágio na escola básica. As orações projetadas desencadeiam a extensão do complexo oracional pela parataxe. Em cada oração justaposta, ao utilizar a construção modal tem que, o aluno-mestre caracteriza as lições 
aprendidas como tipos de regras ou procedimentos de sucesso a serem seguidos para um trabalho pedagógico produtivo (tem que se impor, \{tem que\} dominar, \{tem que $\}$ respeitar, \{tem que $\}$ ser interativo; tem que respeitar). Essas lições foram assimiladas a partir de situações de ensino vivenciadas como exemplares ou não.

Exemplo 09: Considerações finais

Para me foi muito gratificante e enriquecedor ter participado do estagio, pois neste momento tive reflexões sobre minha escolha de ser professora. || | a Confesso || " $\beta 1$ que estava meio desorientada, desanimada, " $\beta \times 2$ a mas segui em frente, || " $\beta \times 2 \times \beta$ a pois acreditava || " $\beta \times 2 \times \beta$ \& que seria indispensável para minha formação esse momento. || | E foi mesmo, pois me descobri pela primeira vez como professora, mas essa experiência me deixou em estado de crise, pois me fez refletir e me desafiei em buscar novas metodologias para está preparada no momento da minha regência e da minha vida profissional como professora. (Licenciatura em Matemática - R5)

O excerto do Exemplo 09 corresponde ao primeiro parágrafo das Considerações finais do relatório investigado. Inicialmente, a experiência é caracterizada como gratificante e enriquecedora devido às reflexões desencadeadas pela prática do estágio. Há um complexo oracional realizado pela projeção de uma elocução (confesso), que constrói a representação da desmotivação sentida pelo aluno-mestre ao iniciar o estágio. Posteriormente, há um complexo oracional realizado pela projeção de uma ideia (acreditava), responsável por representar uma imagem positiva do estágio construída previamente pelo aluno-mestre. Essa imagem faz ecoar vozes de atores sociais que veem os estágios como disciplinas extremamente importantes e, muitas vezes, tardias, pois, inevitavelmente, familiarizam, no início da segunda metade da licenciatura, o aluno-mestre com o futuro local de trabalho, agora, por uma perspectiva diferenciada, visto que o referido ator social passou bastante tempo da vida nas carteiras escolares.

\section{Considerações finais}

Investigamos os usos de complexos oracionais em que as orações primárias são caracterizadas como mentais em relatórios de estágio obrigatório, produzidos por alunos-mestre como atividade avaliativa final da referida disciplina. Procuramos compreender a gênese da escrita acadêmica reflexiva na formação inicial de professores nas licenciaturas. Para tanto, focalizamos o componente experiencial das orações primárias, em especial os participantes e processos selecionados, além do componente lógico 
das orações secundárias paratáticas extensivas, nas ocorrências de orações primárias mentais perceptivas, e das projeções, nas ocorrências de orações primárias mentais cognitivas.

Os processos perceptivos foram os mais recorrentes nas orações primárias, contribuindo especialmente para a construção de representações da infraestrutura e do ambiente laboral vivenciados nos estágios realizados. Essas representações são realizadas textualmente por orações extensivas justapostas, resultando em sequências textuais descritivas e narrativas. Os processos cognitivos projetam posicionamentos críticos mais elaborados pelos alunos-mestre, sendo, muitas vezes, antecedidos por sequências descritivas e narrativas, as quais servem como âncoras para a apresentação da crítica elaborada posteriormente.

Os alunos-mestre foram os atores sociais mais representados como Experienciadores dos processos mentais perceptivos e cognitivos, o que se justifica pela própria natureza gramatical característica do gênero relatório. As realizações gramaticais responsáveis pela indeterminação dos Experienciadores também são características do registro acadêmico investigado, em especial nos momentos do texto em que o conteúdo focalizado se caracteriza como um assunto delicado, a exemplo do desempenho dos professores colaboradores na escola básica. A pouca ocorrência desses professores e alunos como Experienciadores parece um indício do diálogo restrito entre os atores sociais da escola e os alunos-mestre.

Finalmente, podemos afirmar que os momentos de reflexão instaurados pelo uso dos complexos oracionais mentais são bastante relevantes para a construção da prática reflexiva do aluno-mestre. Nessa perspectiva, os usos dessas construções gramaticais podem ser trabalhados pelos formadores em sala de aula, motivando um maior envolvimento dos autores com a escrita produzida, o que poderia, por exemplo, deslocar os relatórios da Licenciatura em Matemática da posição dos textos com menor ocorrência dos complexos oracionais mentais, conforme mostrado na análise comparativa entre documentos de diferentes licenciaturas. ${ }^{17}$

\footnotetext{
${ }^{17}$ Agradecemos imensamente a colaboração e a leitura crítica deste artigo realizada pelo formador da disciplina de Estágio Obrigatório I da Licenciatura em Matemática, responsável pela turma em que foram produzidos os relatórios aqui focalizados. Para manter o anonimato dos dados, evitamos a identificação do referido formador. Agradecemos à Profa. Dra. Sara Regina Scotta Cabral (UFSM) pelo significativo auxílio a esta pesquisa, durante a etapa de análise linguística dos complexos oracionais.
} 


\section{Referências}

ARAGUAÍNA. Projeto Pedagógico do Curso de Licenciatura em Matemática do Campus Universitário de Araguaína. Araguaína: UFT. 215f. 2012. Disponível em: <http:// download.uft.edu.br/?d=2b26fd36-1881-4816-955b-62df5e2b6967:22_2012_ alteracao_no_ppc_de_licenciatura_em_matematica_campus_de_araguaina_5749. pdf>. Acesso em: 25 abr. 2015.

EGGINS, S. An Introduction to Systemic Functional Linguistics. 2 ed. London: Continuum, 2004.

EGGINS, S; MARTIN, J. R. Genres and Registers of Discourse. In: DIJK, T. A. van (Ed.). Discourse as Structure and Process: Discourse Studies: a Multidisciplinary Introduction. London: SAGE Publications, 1997. p. 230-256.

FUZER, C.; TICKS, L.; CABRAL, S. R. S. Análise sistêmico-funcional como suporte para a leitura de textos: o caso da Cerveja Devassa. Revista Brasileira de Linguística Aplicada. Belo Horizonte: UFMG/ALAB, v. 12, n. 4, p. 883-909, 2012. GISI, M. L.; MARTINS, P. L. O.; ROMANOWSKI, J. P. O estágio nos cursos de licenciatura. In: ENS, R. T.; VOSGERAU D. S. R.; BEHRENS M. A. (Org.). Trabalho do professor e saberes docentes. Curitiba: Editora Champagnat, 2009. p. 201-215. HALLIDAY, M. A. K.; MATTHIESSEN, C. M. I. M. Halliday's Introduction to Functional Grammar. 4. ed. London: Routledge, 2014.

LEA, M. R.; STREET, B. V. O modelo de "letramentos acadêmicos": teoria e aplicações. Tradução F. Komesu e A. Fischer Revista Filologia e Lingua Portuguesa, São Paulo, USP, v. 16, n. 2, p. 477-493, 2014.

MARTIN, J. R. Register and Genre: Modelling Social Context in Functional Linguistics - Narrative Genre. In: ZHENHUA, W. (Ed.). Genre Studies: Collected Works of J. R. Martin, v. 3. Shanghai: Shanghai Jiao Tong University Press, 2012. p. 187-221.

MARTIN, J; ROSE, D. Genre Relations: Mapping Culture. London: Equinox, 2008. MATTHIESSEN, C. M. I. M.; HALLIDAY, M. A. K. Systemic Functional Grammar: a First Step into the Theory. China: Higher Education Press, 2009.

MELO, L. C. Formas linguísticas do outro e de si-mesmo na escrita reflexiva acadêmicoprofissional de Relatórios de Estágio de professores de linguas. 2015. 154 f. Tese (Doutorado em Letras: Ensino de Língua e Literatura) - Universidade Federal do Tocantins, Araguaína, 2015.

Agradecemos ainda aos pareceristas anônimos deste texto pelas valiosas contribuições necessárias à publicação neste periódico. Os equívocos ou lacunas que possam restar neste artigo são inteiramente de nossa responsabilidade. 
MELO, L. C; GONCALVES, A. V. Projeções como práticas acadêmicas de citação na escrita reflexiva profissional de relatórios de estágio supervisionados. Raído. Dourados: UFGD/FACALE, v. 8, n. 15, p. 45-70, 2014.

MEURER, J. L. Ampliando a noção de contexto na Linguística Sistêmico-Funcional e na Análise Crítica do Discurso. Linguagem em (Dis)Curso. Tubarão, UNISUL, v. 4, n. especial, p. 133-157, 2004.

SILVA, W. R. Linguística sistêmico-funcional como uma teoria para análise de dados em Linguística Aplicada: escrita reflexiva do aluno-mestre. Documentação de Estudos em Linguistica Teórica e Aplicada-DELTA. São Paulo, PUCSP, v. 31, n. 1, p. 25-68, 2015.

SILVA, W. R. Reflexão pela escrita no estágio supervisionado da licenciatura: pesquisa em Linguística Aplicada. Campinas: Pontes Editores, 2014a.

SILVA, W. R.. Considerações sobre contexto de cultura na Linguística SistêmicoFuncional. In: CONGRESSO INTERNACIONAL DA ASSOCIAÇÃO DE LINGUÍSTICA E FILOLOGIA DA AMÉRICA LATINA - ALFAL, XVII, 2014, João Pessoa. Anais... Estudos Linguísticos e Filológicos. João Pessoa: Idéia, 2014b.

SILVA, W. R. Escrita do gênero relatório de estágio supervisionado na formação inicial do professor brasileiro. Revista Brasileira de Linguística Aplicada. Belo Horizonte: UFMG/ALAB, v. 13, n. 1, p. 171-195, 2013.

SILVA, W. R. Proposta de análise textual-discursiva do gênero relatório de estágio supervisionado. Documentação de Estudos em Linguistica Teórica e Aplicada - DELTA. São Paulo, PUCSP, v. 28, n. 2, p. 281-305, 2012a.

SILVA, W. R. Letramento do professor em formação inicial: interdisciplinaridade no estágio supervisionado da licenciatura. Campinas: Pontes, 2012b.

SILVA, W. R.; ESPINDOLA, E. Schoolteacher represented in pre-service teacher's reflexive academic writing. ALFA: Revista de Linguística. São José do Rio Preto: UNESP, v. 60, n. 1, p. 147-173, 2016.

SILVA, W. R.; ESPINDOLA, E Afinal, o que é gênero textual na Linguística Sistêmico-Funcional? Revista da ANPOLL, v. 1, n. 34, p. 259-307, 2013.

THOMPSON, G. Introducing Functional Grammar. 3 ed. London: Routledge, 2014.

TAVARES, E. Práticas de escrita escolar propostas na formação inicial de professores de diferentes licenciaturas: investigando relatórios de estágio e diretrizes curriculares oficiais. 2011. 151 f. Dissertação (Mestrado em Letras: Ensino de Língua e Literatura) - Universidade Federal do Tocantins, Araguaína, 2011.

Data de submissão: 22/08/2015. Data de aprovação: 02/05/2016. 